\title{
INTRODUCTION
}

\section{Religious Freedom and the Threat of Jurisdictional Pluralism}

\author{
Stefan Rummens \& Roland Pierik
}

State sovereignty is a core element of our liberal democratic political regime. It implies, amongst other things, the idea of comprehensive state jurisdiction. This means that the competence to make laws and enforce them uniquely belongs to the state. In a liberal democracy, this sovereign power of the state is an essential precondition for the realization of the core values of freedom and equality. At the same time, the existence of a private realm in which individuals and groups are free to pursue their conceptions of the good without interference of the state is also an essential and constitutive characteristic of the liberal state. This type of 'private' freedom can, however, only exist if the state itself retains the competence to impose the appropriate constraints ensuring that the freedom of one group or individual does not unduly undermine the equal freedom of other groups or individuals in society. If the core values of freedom and equality are to be realized in an impartial and just manner, this type of line drawing between the freedom of the one and the freedom of the other can and should be a competence residing with the state and with the state only.

This monistic idea of sovereignty seems well established in contemporary liberal democracies. Nevertheless, in her central contribution to this special issue of the Netherlands Journal of Legal Philosophy, Jean Cohen (Nell and Herbert Singer Professor of Political Science and Contemporary Civilization at Columbia University) hammers out an important warning. She argues that two recent landmark decisions of the United States Supreme Court - Hosanna-Tabor and Hobby Lobby have severely damaged this monistic conception of sovereignty in ways that should deeply concern all liberal democrats. In these cases, religiously inspired non-profit and for-profit organizations have been allowed to infringe upon the basic rights of their employees in the name of the religious convictions held by these organizations and their owners. Cohen recognizes, in her paper, that some forms of religious accommodation, in which religious individuals or groups are granted exemptions from general law, can be legitimate within the liberal democratic framework. This does not hold true, however, for the two cases discussed here. The problem is not simply that the decisions are illiberal in the sense that they fail to adequately recognize the legitimate interests of the employees concerned. Cohen is more worried still about the deeper logic underlying the Court's justification of its decisions. Here, Cohen detects an unwarranted deference of the state's authorities to the religious authority invoked by the defendants. At stake in these cases is a sovereignty bid by religious organizations claiming that 
religious authority can trump state authority even in situations where the legitimate interests of third parties might be severely damaged. By granting these cases, the Supreme Court is, therefore, paving the way for a kind of jurisdictional pluralism in which the state sovereign recognizes the legitimacy of a competing religious sovereign holding jurisdiction over areas of society from which the state now retreats. By doing so, the state undermines its own capacity to fulfil its core liberal democratic task of ensuring the freedom and equality of all of its citizens.

In order to assess the important concerns raised by Jean Cohen in her vivid and forceful paper, we have asked five scholars working in the field of religious freedom to respond to her arguments.

The most critical response to Cohen's arguments is provided by Avigail Eisenberg, who emphasizes the difference between the two cases discussed. She agrees with Cohen that the Hobby Lobby decision seems based on some sort of pluralistic logic akin to the jurisdictional pluralism targeted by Cohen. And although Eisenberg acknowledges that this pluralistic argumentation faces serious theoretical problems, she disagrees with Cohen that the Court's justification of its decision demonstrates that group pluralism necessarily leads to illiberal and undemocratic outcomes. The Hosanna-Tabor case, in turn, is - according to Eisenberg - not based on a pluralistic logic at all, but rather follows the explicitly liberal logic of group accommodation, according to which the state needs to actively intervene in order to ensure adequate respect for the legitimate interests of religious citizens. And although it could be argued that the Court failed to make an adequate weighing of all of the relevant interests in this particular case, Cohen's suggestion that the Court thereby defers to an alternative and religious source of authority is exaggerated and misguided.

Sune Lægaard provides us with a helpful analytical disaggregation of the concept of group rights. He emphasizes that we should carefully distinguish between the subjects, the objects, and the grounds of rights. Advocates of church autonomy - what Cohen calls religious jurisdiction - often argue that church autonomy is a necessary precondition for the protection of religious groups through group rights. Lægaard argues, however, that neither the collective nature of the subject of a right (e.g., religious groups) nor the communal nature of the object of a right (e.g., religious beliefs and practices) implies that these rights should be grounded in a collective (e.g., religious) authority other than the state's own sovereign authority. Lægaard thus strengthens Cohen's critique of jurisdictional pluralism in a somewhat indirect manner. Keeping his distinctions in mind, it can be shown that many if not most of the concerns underlying claims for religious accommodation can be dealt with within the liberal constitutional framework and fail to warrant recourse to jurisdictional pluralism.

Jonathan Seglow also agrees with the gist of Cohen's arguments and concerns. In his contribution, he aims to investigate whether group exemptions could be justified on secular rather than religious jurisdictional grounds. The theoretical framework he develops makes use of Cohen's distinction between three possible models 
of corporate legal personhood (the nexus of contracts theory, the concession theory and the real entity theory) as well as Andrew Shorten's distinction between the structure, the purpose, and the ethos of an institution. Seglow emphasizes that a group exemption can only be justified if it can be established that the group as such is somehow unduly burdened by the general law. The concept of a group burden, however, turns out to be rather intractable. The upshot of Seglow's tentative investigation is, therefore, that the justification of group exemptions on secular grounds faces formidable obstacles.

Patrick Loobuyck's paper consists of two parts. In the first part, he develops a broader liberal perspective on the possibilities and limitations of group autonomy. He thereby inquires, amongst other things, into the relevance of the public funding of religiously inspired non-profit organizations such as schools and hospitals. The overall conclusion of Loobuyck's argument is again in line with Jean Cohen's claim that the Supreme Court decisions under consideration are at odds with the core assumptions of liberal democracy. In the second part of his paper, Loobuyck compares American with European jurisprudence with regard to church autonomy. Overall, European jurisprudence seems to be much more in line with the liberal framework. In Europe, religion is given much less weight as a unique and special category compared to other ideologies. And although there is increased pressure for granting more institutional accommodation here as well, democratic sovereignty, on the European side of the Atlantic, is as yet not being challenged in the same way.

In his contribution, Roland Pierik develops a more historical perspective on the central topic of our special issue by distinguishing between a tolerance-leaning and an equality-leaning tradition of liberalism. The tolerance-leaning tradition is the older one and emerged after the outbreak of the Reformation in the early modern age. In this tradition, religious freedom was considered to be a distinctive and pre-institutional first freedom that had to be protected from state infringement. Pierik now analyzes the contemporary claims for jurisdictional pluralism as a resurrection of this older tradition of religious freedom as immunity. Since Pierik himself is committed to the much more demanding equality-leaning ('Rawlsian') tradition of liberalism, he agrees with Cohen's condemnation of the Supreme Court's arguments and conclusions. At the same time, he disagrees with her that the resurrected older logic underlying these arguments could be easily dismissed as 'illiberal' in all possible historical meanings of the term.

In her final reply to critics, Jean Cohen engages with the arguments developed by her respondents. She thereby repeats her concerns about what she calls the 'ominous' court cases under scrutiny. Attempts to revive ideas about jurisdictional pluralism represent a direct threat to the egalitarian principles at the core of our liberal democratic regime and should, therefore, be resisted whenever they arise.

As (guest) editors, we would like to wholeheartedly thank Jean Cohen for kindly accepting our invitation to write the central piece for this special issue and for her willingness to engage in a debate with her respondents. We are equally grateful to 
these respondents for accepting our invitation to participate and for their interesting and constructive contributions. Except for the 'reply to critics', all of the papers published here were previously presented at the joint conference of the Netherlands Journal of Legal Philosophy and the Association of Social and Political Philosophy organized at the Faculty of Law of the University of Amsterdam on 25 and 26 June 2015. 